\title{
SLOVANSKI MITI O EVROPI KOT OBLIKA DIALOGA Z ZAHODOM (PRIMER ČEŠKE IN SLOVAŠKE) ${ }^{1}$
}

Ključne besede: mit, Evropa, Ludovít Štúr

Razprave o evropski književnosti, ki potekajo v sodobni komparativistiki, kažejo na to, da ta pojem nima enoznačne vsebine ter zaenkrat niti izdelane ali splošno priznane metode študija. Evropska književnost ne tvori empirično določene strukturalne celote $\mathrm{z}$ nepretrgano zgodovino in vzročnostjo kot katera koli narodna književnost s svojim jezikom, je bolj predmet različno razumljenih in ideološko zlorabljenih idej (Koprda 1999). ${ }^{2}$ Italijanska raziskovalka Franca Sinopoli v svoji monografiji Mit evropske književnosti (Il mito della letteratura europea, 1999) trdi, da ima evropska književnost pravzaprav podobo mita, ki se kaže kot univerzalna in nadčasovna predstava o enotnosti. Evropska književnost predstavlja na podlagi takega razumevanja kanoniziran način izraza o besedilih, ki ustvarjajo vizijo enotne kulture, ki po mnenju France Sinopoli izhaja iz štirih osnovnih trditev: 1. svetost (pomen knjižnic kot svetih mest znanja, pa tudi moči), 2. prvotnost

1 Študija je nastala v okviru projekta Agencije za subvencije Akademije znanosti Češke republike (GA AV ČR) Vzajemnost in nevzajemnost. Vpogled $v$ češko-slovaške literarne odnose (Vzájemnost a nevzájemnost. Sondy do česko-slovenských literárních vztahů - IAA 900920702).

2 Zahodoevrocentrističen pristop je značilen za npr. monografijo Curtius, E. R. (1998) Evropská literatura a latinský středověk. Praha: Triáda (v nemškem izvirniku Europäische Literatur und lateinisches Mittelalter, 1948), za Hazard, Paul (1935) La crise de la conscience européenne de 1680 à 1715. Paris: Boivin (v poljskem prevodu Kryzys świadomości europejskiej 16801715, 1974) ter Tieghem, Paul van (1941) L'histoire littéraire de l'Europe et de l'Amérique de la Renaissance à nos jours. Paris: Armand Collin. 
(kultura kot združevalni element evropske identitete), 3. vzorčnost (avtoreprezentacija evropske književnosti v obliki zgodovinopisnih koncepcij kot vzora za ves svet) in 4. geografska in predvsem kulturna enotnost. Prizadevanje za kulturno enotnost se pojavi v trenutku, ko začne Evropa izgubljati položaj enotnega imperija, v katerem ni mogoče sporazumevanje v enem obveznem jeziku. Komparatist Jacques Dugast kritizira evropsko kulturno enotnost, ker da gre za predstavo, ki si jo močne in zahodnoevropske književnosti ustvarjajo same o sebi s pomočjo medbesedilne igre tem in nizanja motivov, to pa zato, ker želijo utrditi svoj vodilni položaj. ${ }^{3}$ Nasprotno, kliče po evropski književnosti kot medkulturnem pojavu, ki je sposoben primerjati kulturno različne književnosti in njihove poetike, torej kliče po evropski književnosti kot pogovoru oz. dialogu posameznih evropskih kultur, v katerem se interpretirajo in razlagajo ne samo enakosti, ampak tudi razlike.

Kritiko zahodoevrocentrizma lahko opazimo predvsem v delih slovanskih komparatistov v drugi polovici 20. stoletja (F. Wollman, V. M. Žirmunskij, M. Bakoš, D. Ďurišin itd.), ki so odklanjali pogoste delitve evropskih književnosti na "velike« in "male«, "vplivne« in "vplivane«, torej ideal razvoja, ki temelji na nepravilni predpostavki o enakomernem literarnem procesu posameznih narodnih književnosti. (Npr. Wollman 1928, Žirmunskij 1979/1984, Bakoš 1973, Durišin 1993.) Španski komparatist Claudio Guillén, ki pesniško zbirko Hči Slave (Slávy dcéra, 1824) slovaškega pesnika Jána Kollárja navaja kot primer srednjeevropskega, slovansko-neslovanskega prepletanja narodov, kultur, veroizpovedi in poetik, ${ }^{4}$ sklepa, da je mogoče oblikovati teoretičen model nadnarodnosti, ki raziskuje predvsem splošne razvojne zakonitosti, kot so vprašanja periodizacije ali problemi primerjalne geneologije in poetike, torej področij, ki jih je že Paul Van Tieghem (1946) označil kot "podobnosti brez vplivov «. ${ }^{5}$ Prav češka in slovaška primerjalna

3 Primerjaj zbornik Introduzione alla letteratura comparata. A cura di Armando Gnisci. Rim: Bruno Mondadori 1999, predvsem študijo Gnisci, Armando: Manuale storico di letteratura comparata, 14-60.

4 Primerjaj: Guillén, Claudio (1985) Entre lo uno y lo divierso. Introducción a la literatura comparada. Barcelona: Editorial Crítica (z Jánom Kollárjem je Guillén ukvarja v drugem poglavju).

5 Tieghem, Paul Van (1946) La littérature comparée. Paris: Collection Armand Collin (3. izdaja). O podobnostih brez vplivov govori Tieghem v drugem odstavku 3. dela La littérature générale). 
književnost je v prvi polovici 20. stoletja prispevala k uveljavljenju mnenja o kulturnem ravnovesju med zahodom in vzhodom ter h kritiki zahodnoevropskega načela »slavica non leguntur«. S tem je izrazila svoj nazor o enotnosti in nedeljivosti književnosti, ki so nastale na različnih delih evropske celine, ter na idejo, ki je navezovala na goethejevsko vizijo univerzalizma kot vrednotno enakovredne »izmenjave kulturnih dobrin [...] in sistematsko gojenje mednarodnih kulturnih stikov«. (Hrabák, 1976, 110)

Češko-slovaška šola primerjalne književnosti je bila od generacije, ki jo je ustanovila (J. Polívka, J. Máchal, M. Murko, V. Tille itd.), in njihovih učencev (K. Krejčí, F. Wollman, R. Wellek itd.) vse do S. Wollmana in D. Durišina šola, ki je presegala pozitivistično vplivologijo in ni priznavala nasprotja med »manj razvitimi« in »bolj razvitimi« književnostmi, ki je temeljilo na predstavi enosmernega vpliva. (prim. Wollman, 1989) Njihove raziskave so pokazale pomen enotnosti slovanskih narodnih književnosti in njihovih medsebojnih stikov z razvojem svetovne književnosti, ki »kot jedro splošnih zakonitosti in razvojnih tendenc služi kot osnovna orientacija tudi za domače avtorje, narodni književnosti pa zadošča, da pravočasno [...] vsrka vse svetovne literarne vplive«. (Parolek, 1968, 206) Češki slavist in polonist Karel Krejčí je imel trditev o nasprotju med evropskim zahodom in slovanskim vzhodom za mit - fiktivne predstave, ki resničnost interpretirajo po koščkih -, ki pa zaradi svoje razširjenosti postane zgodovinsko dejstvo. Trdil je torej, da odnose med vzhodom in zahodom, ki jih lahko poenostavimo na odnos med slovanskim in neslovanskim, opredeljuje dialog in komunikacija, ki poteka preko t. i. narodnih mitov, ki delujejo konstruktivno ali destruktivno. S tega stališča je mogoče odnos zahoda do slovanske kulturne enotnosti analizirati različno. Po eni strani je jezikovno-etnična sorodnost, ki je obstajala v podobnih literarnih oblikah in žanrih, skupaj z občutki plemenske pripadnosti pomenila predstavo o enotni strukturi, po drugi strani pa so bile možnosti primerjave slovanskih književnosti ogrožene zaradi razdelitve Slovanov na različne kulturne in politične sfere, ki jo je povzročilo dejstvo, da »je problem slovanske enotnosti v sporu s problemom nasprotij med zahodom in vzhodom «. (Krejčí, 1968, 198) Krejčí je začetke tega procesa videl v cerkvenem razkolu, v konfliktu med rimskokatoliško in pravoslavno cerkvijo, ki pa je izviral iz skupne zapuščine - iz antične civilizacije. Med Slovani in zahodom je tako neprestano potekal dialog v 
obliki stalnega približevanja in oddaljevanja, v katerem so imeli posebno mesto zahodni Slovani živeči v habsburški monarhiji. Po mnenju Krejčija se oscilacija in »razdvojenost« med zahodom in vzhodom kaže predvsem pri Poljakih in Čehih, ki »v cerkveni in politični organizaciji tvorijo del zahoda« (ibid.), hkrati pa se pri njih pojavlja »zavedanje plemenskega sorodstva $z$ največjim pravoslavnim narodom «. (ibid.)

Če so imeli do 18. stoletja v odnosu neslovanskega zahoda in slovanskega vzhoda pomembno vlogo cerkveni in veroizpovedni kriteriji, so od obdobja narodnostno-socialne in državnopravne emancipacije majhnih slovanskih narodov na prelomu 18. in 19. stoletja dobivali večji pomen civilizacijski vidiki - začela se je obojestranska izmenjava kulturnih vrednot in narodnih mitov kot kolektivno širjenih stereotipov. Dialog se je tako razvijal od konfesionalizacije $\mathrm{k}$ nacionalizaciji, konflikt med katoliško-protestantsko ter pravoslavno enotnostjo je nadomestila napetost med germansko-romansko ter slovansko Evropo. Krejčí je sicer trdil, da je na slovanski strani »očiten primanjkljaj«, prevlada enosmernega kulturnega izposojanja vplivov in idej prihajajočih $\mathrm{z}$ zahoda na vzhod, a razlika »ne izhaja niti iz pomanjkanja zanimanja niti iz pomanjkanja vrednot, temveč iz težav $v$ njihovi prenosljivosti«, (ibid.: 199) torej iz oblik in načinov medsebojne komunikacije. Slovani, predvsem predstavniki inteligence, so zahodno Evropo poznali s svojih študijskih potovanj in iz neposrednih stikov, iz osebno doživete avtopsije, brali so dela francoskih, nemških in angleških klasikov v izvirniku, sprejemali in prevzemali so tudi druge kulturne vrednote. Zahod pa je vzhod večinoma ignoriral oziroma je njegove prebivalce pogosto razumel kot kulturne barbare, njihovo ozemlje pa je na zemljevidih označeval z napisom hic sunt leones. Poznavanje slovanske kulture so dosegli le posamezniki iz vrst filologov - znanstvenikov, misijonarjev, popotnikov, diplomatov itd. Krejčí trdi, da je začel zahod slovanski svet odkrivati že v 18. stoletju in se je k vzhodu približeval predvsem preko Rusije, ki se je zaradi reform Petra Velikega evropeizirala. Pojavilo se je novo razumevanje Evrope - kot jezikovno-etničnih celot, definiranih s kulturno-psihičnimi arhetipi, kar je ustvarjalo pogoje za nastanek narodnih mitov, ki so omogočali tvorjenje nepravih kolektivnih predstav predvsem v odnosu zahoda do Slovanov. Krejčí je pri sprejemanju slovanskih vrednot na zahodu v 18. stoletju ločil tri osnovne mite, ki so delovali tudi v kasnejšem obdobju: 
1. občudovanje, ki sta ga pri francoskih enciklopedistih in Voltairu vzbujala carica Katarina Velika in rusko samodržavje kot demokratični ideal družbene ureditve in izpolnitve razsvetljenskih idej o pravičnosti sveta; 2. obraten mit francoskih protimonarhistov (J. J. Rousseau), ki so idealizirali poljsko plemištvo in njegova protiruska stališča; 3. najbolj razširjen mit o Slovanih je ustvaril nemški preroditelj J. G. Herder v svojem delu Ideen zur Philosophie der Geschichte der Menschheit (Ideje o filozofiji zgodovine človeštva), v katerem je povzdignil »golobičji« značaj Slovanov in jim priznal vodilno vlogo v svetovni zgodovini. Krejčí je tem mitom v komunikaciji zahoda s Slovani pripisoval obojestransko funkcijo - miti so kljub svojemu dvomljivemu značaju "vplivali na zahodnoevropske nazore o slovanstvu«, vendar so "pokazali tudi ustvarjalno silo, ki je bila sposobna iz fikcije ustvariti resničnost«. (ibid.: 201)

Kot primer fikcije in političnega mita, ki je namensko manipuliral s sliko geografsko-politične ureditve Evrope in ki je vplival na resničnost ter na praktična stališča večjega dela slovaške intelektualne elite, lahko služi »pozabljeno« delo slovaškega narodnega buditelja Ludovíta Štúra Das Slawenthum und die Welt der Zukunft (Slovanstvo in svet prihodnosti, 1851). Štúr je bil kot ideolog slovaškega narodnega preporoda pomemben zaradi kodifikacije knjižne slovaščine (1843), zaradi katere je s češke strani dobil nalepko »uničevalca « češkoslovaške kulturne in politične enotnosti. Slovaško zgodovinopisje se v razumevanju Štúra še danes do določene mere razhaja, strinja pa se glede vrednotnega dualizma štúrovske tradicije. (primerjaj: Bilasová in drugi 2004, 2005) Ta je po eni strani postala osnova modernega narodnega obstoja, utrdila je narodno zavest in Slovake kulturno, politično in versko združila okoli krščanskih idej in nacionalnega panslavizma. Po drugi strani pa je štúrovska tradicija prinesla jasno pretrganje vezi $\mathrm{z}$ zahodnoevropskim kulturnim in civilizacijskim prostorom ter s tem povzročila določen vakuum vrednot ter zagotovo tudi zaostajanje $\mathrm{v}$ zapletenem srednjeevropskem, slovansko-neslovanskem kontekstu, v katerem se intenzivno prepletajo narodi, veroizpovedi, jeziki, kulture in književnosti. Štúrovo sporočilo o zgodovinskem poslanstvu Slovakov in o njihovi kasnejši usmeritvi je izhajalo iz Heglovega teleološkega razumevanja zgodovine: po mnenju Štúra predstavlja bistvo slovaškega naroda metafizična duhovna substanca, ki se kaže kot ideja dobrega. Slovaki so samostojen narod v 
svetovni zgodovini, ki lahko mesijansko uresničuje in polni idejo dobrega ter povzdiguje človeštvo $\mathrm{k}$ Bogu. Štúrovo politično sporočilo je bilo razumljeno na različne načine že od časa svojega nastanka. Češki filozof in prvi predsednik Češkoslovaške republike Tomáš Garrigue Masaryk, katerega koncepcija je temeljila na združitvi Čehov in Slovakov v eni skupni državi, je povzdigoval predvsem demokratičen humanizem slovanske vzajemnosti Jána Kollárja, ki temelji na razumevanju in dialogu; Štúr je za Masaryka predstavljal nevarnost militantnega nacionalizma in političnega diletantizma. (Masaryk 1996) Za slovaške fašistično usmerjene politike je ta slovaški domoljub predstavljal ikono etnične in rasne čistosti Slovakov ter človeka, ki je dokončno uresničil slovaški nacionalni socializem ter zaslutil nevarnost semitizma in judovskega elementa v domači zgodovini. Slovaški politik in notranji minister v času druge svetovne vojne Alexander Mach je Štúra slavil kot »slovaškega Hitlerja 19. stoletja «. ${ }^{6}$ In obratno - Machov sodobnik, komunist Vladimír Clementis (usmrčen v začetku 50. let 20. stoletja kot žrtev buržoaznega nacionalizma) v svojem delu, nastalem $\mathrm{v}$ izgnanstvu, $\mathrm{z}$ naslovom Slovaki in slovanstvo (Slováci a Slovanstvo, 1944) sicer ni govoril o Štúrovem protikomunističnem in protimarksističnem stališču - Štúru ni bil všeč Marxov materializem, ateizem in liberalizem ter njegovo sovraštvo do Slovanov -, po drugi strani pa je Clementis enostransko povzdigoval štúrovsko usmeritev k vzhodu, k slovanski Rusiji kot izrazu aktualne izpolnitve revolucijske zakonitosti zgodovine. (prim. Clementis 1944)

Štúr je svoje delo Das Slawenthum und die Welt der Zukunft napisal v nemščini v začetku 50. let 20. stoletja (v prisilni izolaciji v Modri) kot svojo politično oporoko, $v$ kateri je poskusil določiti smisel slovaške zgodovine na ozadju splošnega evropskega razvoja. Knjiga je bila najprej prevedena v ruščino, prvič pa jo je leta 1867 uradno izdal ruski slavjanofil V. I. Lamanskij v času slovanskega kongresa v Moskvi istega leta. Šele leta 1931 je češki slavist Josef Jirásek, ki je predaval rusko književnost na Univerzi Komenskega v Bratislavi, odkril Štúrov nemški izvirnik, ki ga je opremil in izdal pod naslovom Das Slawenthum und die Welt der Zukunft. Celotno delo je v slovaščino iz Jiráskove izdaje prevedel Adam Bžoch, prevod pa je

6 Citirano po: Majchrák, Jozef (2007) „Ludovít v službách režimov.“ Týždeň 17/4, 17 (gre za izjavo slovaškega zgodovinarja Ivana Kamenca). 
izšel šele leta 1993 in takrat se je z njim seznanila tudi širša javnost. A kljub temu delo po 150 letih pomembno pozitivno, pa tudi negativno vpliva na slovaško književnost, kulturo in politiko.

Štúr je ubesedil nov mit Evrope, ki je po njegovem naravno razdeljena na »materialistični« zahod in »duhovno-zgodovinski« vzhod. Zahodni narodi, vključno z Nemci in Čehi, so materialno preseženi in niso izpolnili svojega zgodovinskega poslanstva, medtem ko slovanski narodi na vzhodu, na prvem mestu Slovaki, šele zdaj prihajajo na zgodovinsko sceno. Politična prihodnost Slovanov in Slovakov bo izhajala iz tesnega sodelovanja $\mathrm{z}$ Rusijo. Če tako ni mogoče ustvariti slovanske federacije brez Rusije, prav tako pa se tega kolosa ne da preoblikovati v slovansko federacijo, potem je edina rešitev unija $\mathrm{z}$ Rusijo $\mathrm{v}$ obliki absolutistične monarhije, versko združene v pravoslavni cerkvi. Slovaki morajo torej žrtvovati knjižno slovaščino v korist ruščine, pisane s cirilico, pa tudi prestopiti v pravoslavno vero, ki za Štúra izvira iz prvotne, grško-slovanske vere. Štúr se giblje v nezdružljivih nasprotjih, v binarnih opozicijah (mi-oni, zahod-vzhod, svoboda-enakost, individualizem-kolektivizem itd.), s katerimi meri geografsko-kulturne regije Evrope. Iz tega izhaja njegov patetičen in čustveno dodelan slog, definicijske komparacije in eksplikacije, imperativen in apelirajoč način mišljenja, ki bralcem ne pušča nobenega prostora za razmišljanje. Evropo je treba po njegovem mnenju razdeliti » $\mathrm{z}$ železno zaveso «, ki bo zahodu onemogočila izvažati nizke materialne vrednote kot parlamentarno demokracijo ali tržno gospodarstvo v smeri proti Rusiji, kjer vlada kolektivna »občina« in "pravično samodržavje«. Slovaški teoretik in semiotik Tibor Žilka trdi, da je Štúrova edinstvena modifikacija slovanske vzajemnosti do določene mere "postmoderna « utopija s katastrofalnim koncem, kajti »implozija $\mathrm{v}$ prostor s kulturnega vidika resno ogroža globalno in kompleksno utopijo slovanske vzajemnosti in izostruje pogled na to, kar je ostalo od samega začetka kultur, torej od tega, kar je nastajalo dolga stoletja«. (Žilka 2000: 181) Štúrova filozofska koncepcija zgodovine hkrati zanika še en mit, in sicer vizijo srednje Evrope, ki »je tudi v času totalitarizma ohranjala zahodne vrednote, a se je $\mathrm{v}$ družbeni, politični in ideološki sferi družba bližala bizantizmu in cezaropapizmu«. (ibid.: 180) Štúrova delitev Evrope tako popolnoma izpušča razumevanje srednje Evrope, kamor Slovaki kulturno in politično spadajo, kot križišča ali sinteze različnih mišljenjskih vplivov 
in tokov. Odpravlja koncepcijo Evrope sodelujočih regij in daje prednost razumevanju Evrope kot nezdružljivih narodnih domovin.

Jasno je, da morajo analize, ki vrednotijo zgodovinsko nujnost Štúrovega stališča, vzeti v obzir tedanji geopolitični položaj majhnega slovaškega naroda, ki se je z Madžari boril za svoj obstoj in ki se je razvijal v okviru skupne ogrske celote. S tega vidika je mogoče razumeti Štúrovo »zaščitniško « držo na sledeč način: 1 . Slovaki ne morejo ostati brez strateškega partnerja, ta pa mora biti slovanska Rusija; 2 . Zahod predstavlja s svojim ideološkim liberalizmom največjo nevarnost za svoboden razvoj slovaškega naroda. Za prihodnost pa ostaja odprto vprašanje zgodovinske smiselnosti slovaških, in torej tudi evropskih korenin v duhu štúrovske tradicije. Te so namreč prispevale k mitizaciji zgodovine naroda, pa tudi k mitizaciji predstave, s katero Slovaki kot srednjeevropski narod gledajo na Evropo. To refleksijo lahko zaključimo tako, da na tem mestu navedemo tudi nič manj kontroverzen esej slovaškega intelektualca, ki ni povezan s humanističnimi vzorci našega razmišljanja. Slovaški biolog Ladislav Kováč je nekaj mesecev pred prelomnimi dogodki leta $1989 \mathrm{v}$ eseju Razmišljanje o znanosti in naši zgodovini (Premýšlanie o vede a našich dejinách) radikalno zaostril vprašanje štúrovskih tradicij v skupni Evropi. Štúr in njegovi privrženci so po njegovem mnenju nasilno razbili miselno tradicijo povezano z Ogrsko, estetsko kanonizirali ljudsko pesem, ki so jo imeli za višek umetnosti, ter Slovake s tem (kljub etnični ohranitvi) civilizacijsko izolirali od okoliškega sveta in hkrati zmitizirali slovaško dojemanje sosednjih narodov in Evrope: »To je vedlo $k$ napaki, ki jo moramo brez poveličevanja poimenovati kot tragično. Odrekli so se ogrske zgodovine. Vzeli so nam zgodovino! Zgodovino, ki smo jo soustvarjali ne samo kot kmetje, ki so garali na gosposki zemlji, ne samo kot pastirji ovac na pašnikih, ampak kot aktivni udeleženci dogajanja na Ogrskem, kot soavtorji ogrske kulture, kot ustvarjalci arhitekture Bardejova, Banskej Štiavnice, Bratislave ...«(Majchrák 2007: 20) 


\section{LITERATURA}

Bakoš, M., Literárna história a historická poetika. Príspevky k metodológii literárnej vedy, Bratislava, 1973.

Clementis, V., Slováci a Slovanstvo, London, 1944.

Curtius, E. R., Evropská literatura a latinský středověk, Praha, 1998. V nemškem izvirniku Europäische Literatur und lateinisches Mittelalter, 1948.

Ďurišin, D., Osobitné medziliterárne spoločenstvá 6. Pojmy a princípy, Bratislava, 1993.

Gnisci, A., Manuale storico di letteratura comparata. V: Introduzione alla letteratura comparata. A cura di Armando Gnisci. Roma, 1999, str. 1460.

Guillén, C., Entre lo uno y lo divierso. Introducción a la literatura comparada, Barcelona, 1985.

Hazard, P., La crise de la conscience européenne de 1680 à 1715, Paris, 1935.

Hrabák, J., Literární komparatistika, Praha, 1976.

Koprda, P. et al., Medziliterárny proces I. Medziliterárne aspekty staršej literatúry, Nitra, 1999.

Krejčí, K., Mýtus a dialog v historických vztazích Slovanstva se Západem. V: Československé přednášky pro VI. mezinárodní sjezd slavistů v Praze, Praha, 1968.

Majchrák, J., Ludovít v službách režimov, Týždeň 17/4, 2007, 17.

Masaryk, T. G., Rusko a Evropa I-II, Praha, 1996.

Parolek, R., Poznámky k nerovnomèrnosti literárního vývoje slovanských literatur. V: Československé přednášky pro VI. mezinárodní sjezd slavistů v Praze, Praha, 1968, 206.

Sinopoli, F., Il mito della letteratura europea, Roma, 1999.

Štúr, L., Slovanstvo a svet budúcnosti, Bratislava, 1993 (preklad A. Bžoch). 
Tieghem, P. Van, L'histoire littéraire de l'Europe et de l'Amérique de la Renaissance à nos jours, Paris, 1941.

Tieghem, P. Van, La littérature comparée, Paris, 1946.

Bilasová, V., / Dupkala, R., / Žemberová V., (ur.), Fenomén Slovanstva, jeho filozofické, teologické, politologické a literárnohistorické reflexie na Slovensku I. Prešov, 2004.

Bilasová, V., / Dupkala, R., / Žemberová, V., (ur.), Fenomén Slovanstva II. Prešov, 2005.

Wollman, F., Slovesnost Slovanů, Praha, 1928.

Wollman, S., Česká škola literární komparatistiky (Tradice, problémy, prínos), Praha, 1989.

Žilka, T., Utópia z hladiska postmoderny. V: T Žilka. Postmoderná semiotika textu. Nitra, 2000, 180.

Žirmunskij, V. M., O hrdinském eposu (slovanském a středoasijském). Praha, 1984. 


\title{
SLAVIC MYTHS ABOUT EUROPE AS A FORM OF DIALOGUE WITH THE WEST \\ (CZECH AND SLOVAK EXAMPLES)
}

Keywords: myth, Europe, Ludovít Štúr

\begin{abstract}
The study deals with myths which feature in literary communication between Western Europe and the Slavic East. Slavic peoples and the West carried on a continual dialogue - a process of moving closer and further apart - with a special role being occupied by the Slavs living in the Habsburg Empire. The paper highlights the contribution of Krejčí, a prominent Czech scholar in the field of Slavonic studies, who pointed out that Slavic fictions often reflected or in turn became part of historical reality. For example in the Slovak case, an ideology - based on L. Śtúr's Das Slawenthum und die Welt der Zukunft (1851) - developed, which, though a tendentious myth, influenced the formation of Slovak national identity. In his political testament Štúr made an attempt to define the "goal« of Slovak history against the background of European development. According to Šturr, the future of the Slovak people lay in political union with Russia, in adopting the Cyrillic alphabet and the Orthodox Church, and in the rejection of materialistic Western values. Štúrian tradition, may have, as a myth strengthened national self-confidence, but at the same time it meant cutting ties with Western European culture and civilisation, and as a result led to the rejection of the idea of Europe as cultural unity comprising distinct but mutually influencing regions.
\end{abstract}

